\title{
Mediating role of innovative climate among leadership and employee performance in textile exporting firms of Pakistan
}

DOI: $10.35530 / I T .072 .06 .20206$

FAZAL HUSSAIN AWAN

RANA FAIZAN GUL

DUNNAN LIU

ALIYA ANWAR

KHALID JAMIL

GUANGYU QIN

\section{ABSTRACT - REZUMAT \\ Mediating role of innovative climate among leadership and employee performance in textile exporting firms of Pakistan}

This research seeks to examine how transformational leadership and ambidextrous leadership impact employee performance. The study focuses on the mediating role of innovation climate in influencing the relationship both directly and indirectly with employee performance. Previous literature shows that many studies have been conducted to measure the employee's performance under the leadership. Still, no study has covered the mediating role of innovation climate between leadership and employee performance. The present study aims at filling that gap through the presentation of a statistical model. Respondents in the sample included the managerial staff of textile exporting firms of Pakistan. Multiple linear regression and the PROCESS for mediation model in the SPSS was used to analyze the collected data. The results indicated that the CEO transformational leadership and ambidextrous leadership had a significantly positive influence on employee performance. In addition, innovation climate was found to have a strong mediating effect. The researchers recommended the exploration of the impact of other possible moderating variables in future researches. Recommendations were also made for the top management of textile firms for the consideration of innovation climate along with the improvement of employee performance.

Keywords: CEO transformational leadership, ambidextrous leadership, innovative climate, employee performance, textile export, Pakistan

Rolul de mediere al climatului inovator privind leadershipul și performanța angajaților în firmele exportatoare de textile din Pakistan

Această cercetare își propune să examineze modul în care leadershipul transformațional și leadershipul ambidextru influențează performanțele angajaților. Studiul se concentrează pe rolul de mediere al climatului de inovare în influențarea relației atât direct, cât și indirect a performanței angajaților. Literatura anterioară arată că au fost efectuate multe studii pentru a măsura performanța angajatului sub leadership. Cu toate acestea, niciun studiu nu a acoperit rolul de mediator al climatului de inovare dintre leadership și performanța angajaților. Prezentul studiu își propune să umple acest gol prin prezentarea unui model statistic. Respondenții din eșantion au inclus personalul managerial al firmelor exportatoare de textile din Pakistan. Regresia liniară multiplă și modelul PROCESS for mediation în SPSS au fost utilizate pentru a analiza datele colectate. Rezultatele au indicat că leadershipul transformațional CEO și leadershipul ambidextru au avut o influență semnificativ pozitivă asupra performanței angajaților. În plus, climatul de inovare s-a dovedit a avea un puternic efect de mediere. Cercetătorii au recomandat explorarea impactului altor posibile variabile de moderare în cercetările viitoare. De asemenea, au fost făcute recomandări pentru top managementul firmelor textile pentru luarea în considerare a climatului de inovare împreună cu îmbunătățirea performanței angajaților.

Cuvinte-cheie: leadership transformațional CEO, leadership ambidextru, climat inovator, performanța angajaților, export de textile, Pakistan

\section{INTRODUCTION}

Innovation in textile firms has become the main driver of creating a competitive advantage [1]. It has led to changes in the ways textile firms compete in a single industry and has directly affected their ability to survive. The textile firms that do not innovate will probably not stay in the market for long [2, 3]. Innovation is more than newness, inventions, creativity $[4,5]$, which is mainly used by textile firms to present a positive image of their brands. Innovation culture helps firms to expand their business as well as attract new clients [6]. New ideas and innovative products are straightforward to introduce in the textile sector, but launching and commercialising these ideas is challenging. As a result, most textile firms fail to take place in competitive export markets due to innovative ideas [7].

Scholars and managerial practitioners have identified leadership behaviours as the most influential drivers of innovation climate [8]. Executives can create an environment within their organizations that support innovation [6]. This includes developing the skill sets necessary for the innovation process, such as forming structures, allocating resources, putting the latest 
techniques in the workplace, creating learning environments, being open to outside ecosystems, and accepting failure are considered the essential parts of learning [6]. Managerial scholars argue that the notion of an innovative leader is different from that of an innovation leader. However, some in academia and material practices still misunderstand the difference between these two concepts $[9,10]$. The concept of an innovative leader relates to the leader's skills and traits. This type of leader is a source of creativity who can bring in new thinking and prescribe different actions regarding leading, managing, and moving forward with work. An innovative leader can think of different ways to overcome organizational challenges or deal with a scarcity of information [11]. In contrast, an innovation leader focuses on creating an organizational environment with a climate of innovation that supports innovation within teams. In this environment, employees can implement innovative practices that lead to new products or services [12]. In addition, an innovation leader does not just hire creative resources. Instead, an innovation leader helps teams think of new ways to capture value, work within resource constraints to develop and manage processes, achieve a competitive advantage, and ultimately organizational survival $[13,14]$. Overall, a growing knowledge of leadership practices and innovation is evident among those in management and academic literature [15]. However, modern researchers argue that if a leader wants innovative and quality outcomes, he must mix different leadership skills and have strong interaction quality [16]. Thus, innovation leaders need to identify and develop the skills that are appropriate for impacting innovation. After all, they are the ones who are responsible for infusing their organizations with practices that foster employee performance [8].

This study will extend the existing body of knowledge on CEO transformational leadership and ambidextrous leadership relationships by investigating innovation climate mediation with employee performance. Moreover, it will sensitize practitioners on how CEO transformational leadership and ambidextrous leadership directly affect employee performance. Furthermore, when mediated by innovation climate, it will inform them about the remedial measures against the effects of leadership on innovation. Finally, it will also provide a basis for further investigation on different dimensions of leadership in an organization.

This study investigates the direct positive relationships between CEO transformational leadership, ambidextrous leadership, and employee performance. In addition, it checks the mediating role of innovation climate among CEO transformational leadership, ambidextrous leadership, and employee performance. The unit of analysis of this study is the managerial staff of textile exporting firms in Pakistan.

\section{Literature review}

\section{The role of CEO transformational leadership}

A transformational leader can be defined as "a dynamic person who is far away from personal interests, having a charismatic and influential personality, having the inspirational ability, an intellectual with unique ideology" [17]. A transformational leader can see in the future and save his organization from recessions and use his ability to achieve the organisation's goal. In the presence of a transformational leader, his followers' expectations and enthusiasm increased as their leader set the organization's goal achievable, rational and tangible. To get innovative outcomes, leaders need to adopt a transformational style that will help them explore new ideas [18]. When leaders adopt the transformational style, it allows organisations to explore innovation, create a learning environment for employees, improve safety standards, think positively, rectify errors, and improve employee empowerment by using positive behaviour. As a result, the innovative climate of an organization can be enhanced with the implementation of all these elements [3,19].

\section{The role of ambidextrous leadership}

Ambidextrous leadership is a new leadership theory that was put forth by German strategy professors [11]. Funded by Volkswagen information technology company, O'Reilly and Tushman [11] conducted a comprehensive research study which implemented a metanalysis of existing literature that linked leadership effectiveness with innovation performance. [20] focused on determining the behaviours that influenced business innovation most effectively and looked explicitly at leaders who had direct contact with innovation teams. The dilemma related exclusively to the two ends natures of the innovation process, which are creativity and implementation. They require opposing and contradicting leading behaviours (i.e., opening and closing behaviours) [21]. Determining the complementary leadership behaviours necessary for innovation and how team leaders can help teams and individuals implement them and become more innovative was a significant concern $[22,23]$.

Rosing et al. [20] discussed that ambidextrous leadership performs well in an organisation that promotes innovative culture because it can work under opposite and diverse situations in the same manner. Opening behaviours encourage new experiments after unique ideas. It leads to setting up new manners to fulfill assigned tasks, promote risk taking, encourage to execute new ideas and learn from mistakes [24]. On the other hand, closing behaviours support discriminating policies at the implementation stage. It refers to coaching, goal achievement, setting up new goals, performance enhancement programs, dedication to following the rules, minimising errors, and implementing plans. Investigations show that creativity and control are opposite between the teams [18], and the leaders who were capable of adopting an innovative environment in the organization were very 
reluctant. They can level up between both behaviours according to the project's demand $[25,26]$.

Innovation occurs in two levels: the organizational level and the team level [27]. Therefore, the complexity of innovation leadership is feed by the overlapping roles and activities that depend on the hierarchy of an organization. Leaders should employ a transformational leadership style to influence organizational innovation, whereas team leaders should use ambidextrous leadership to respond to variations in innovation outcomes [26].

\section{The mediating role of innovative climate}

Soken et al. [28] claim that in organizations, executives benefit from innovation environments. However, an innovation that enables organizational climate is not created by chance. It results from an organization's strategy, a supportive culture, and influential leaders willing to learn from failure. According to a worldwide survey [29, 30], over $94 \%$ of executives indicated that people and climate are the two most important drivers of innovation in organizations. They put human capital at the centre of their strategies and are aware that an organisation's climate can promote or poison creativity and innovation [31]. However, having an organizational climate that only rewards innovative ideas and behaviours is not enough [30]. Organizational climate should also support open communication and multi-level collaboration across functional teams; empower teams by getting support from company executives; encourage risk-taking, flatter organization structures, feedback, and intensive cooperation with stakeholders; and let stakeholders participate in the innovation process and its outcomes [21].

\section{MATERIAL AND METHODS}

The present study was conducted in textile exporting firms of Pakistan. This research is quantitative, and a well-structured adapted questionnaire was designed to collect the primary data from the managerial level staff of textile exporting firms of Pakistan by using a nonprobability convenient sampling technique. Two hundred and fifty questionnaires were delivered to targeted respondents through email and gave them one month to fill the questionnaire and returned it to the researchers. After one month, 220 questionnaires were received, from which twenty questionnaires were found incomplete and excluded from the final sample. After this, 200 valid and complete responses were added for analysis. The respondents' response was judged on a five-point likert scale consisting of 1 for strongly disagree and 5 for strongly agree. The questionnaire items were already used and had strong reliabilities in the context of Pakistan and other countries. Sources of these items are mentioned in table 1. For data analysis Statistical Package for the Social Sciences (SPSS) have been used.
Table 1

\begin{tabular}{|c|l|c|c|c|}
\hline \multicolumn{5}{|c|}{ MEASURES USED FROM EXISTING STUDIES } \\
\hline $\begin{array}{c}\text { Sr. } \\
\text { no. }\end{array}$ & Construct & Items & Reference & $\begin{array}{c}\text { Cronbach's } \\
\mathbf{\alpha}\end{array}$ \\
\hline 1 & $\begin{array}{l}\text { Transformational } \\
\text { leadership }\end{array}$ & 7 & $\begin{array}{c}\text { Berends } \\
\text { et al. [7] }\end{array}$ & 0.80 \\
\hline 2 & $\begin{array}{l}\text { Ambidextrous } \\
\text { leadership }\end{array}$ & 6 & $\begin{array}{c}\text { Farr } \\
\text { et al. [2] }\end{array}$ & 0.90 \\
\hline 3 & $\begin{array}{l}\text { Innovative } \\
\text { climate }\end{array}$ & 4 & $\begin{array}{c}\text { Jansen } \\
\text { et al. [18] }\end{array}$ & 0.87 \\
\hline 4 & $\begin{array}{l}\text { Employee } \\
\text { performance }\end{array}$ & 7 & $\begin{array}{c}\text { O'Reilly } \\
\text { et al. [16] }\end{array}$ & 0.85 \\
\hline
\end{tabular}

\section{RESULTS}

\section{Descriptive analysis}

A total number of 250 questionnaires were sent to the respondents through email. After one month, 220 questionnaires were received, of which 20 were found incomplete and excluded from the final sample. Therefore, the response of 200 respondents was entered into SPSS for analysis. To analyze the descriptive characteristics, the respondents' age, qualification, designation, and experience were discussed, which is presented in table 2.

Table 2

\begin{tabular}{|c|c|c|}
\hline \multicolumn{3}{|c|}{ DESCRIPTIVE ANALYSIS } \\
\hline Constructs & Items & Percentage \\
\hline \multirow{4}{*}{ Age } & Up to 25 years & 15 \\
\cline { 2 - 3 } & $25-35$ years & 20 \\
\cline { 2 - 3 } & 36-46 years & 35 \\
\cline { 2 - 3 } & Above 46 years & 30 \\
\hline \multirow{4}{*}{ Qualification } & Graduation & 36 \\
\cline { 2 - 3 } & Masters & 40 \\
\cline { 2 - 3 } & Above Masters & 24 \\
\hline \multirow{4}{*}{ Designation } & Deputy Manager & 22.5 \\
\cline { 2 - 3 } & Manager & 47.5 \\
\cline { 2 - 3 } & General Manager & 30 \\
\hline \multirow{4}{*}{ Experience } & Up to 3 years & 10 \\
\cline { 2 - 3 } & 3-6 years & 25 \\
\cline { 2 - 3 } & $7-10$ years & 30 \\
\cline { 2 - 3 } & Above ten years & 35 \\
\hline
\end{tabular}

\section{Multiple regression}

Multiple linear regression was performed to check the relationship between transformational leadership, ambidextrous leadership and innovation climate on employee performance. After the analysis, the model was significant as $(p<0.01)$, and the value of F-statistics is 57.92. The coefficient of determinants $\left(R^{2}\right)$ value is 0.518 , which shows that $51.8 \%$ change in employee performance is due to these three independent variables (Transformational Leadership, Ambidextrous Leadership, Innovation Climate) rest of 
the shift may be due to other variables which are not included in the model.

Furthermore, the results of multiple linear regression show that all three variables have a significant and positive impact on the dependent variable as $p<0.05$. The standardized coefficient $(\beta)$ for each independent variable is transformational leadership (0.313), ambidextrous leadership (0.293) and innovation climate (0.420) show that all independent variables have a positive and significant impact on employee performance.

Table 3

\begin{tabular}{|c|c|}
\hline \multicolumn{2}{|c|}{ REGRESSION RESULTS } \\
\hline Model variable & Standardized $\boldsymbol{\beta}$ \\
\hline Transformational Leadership & 0.313 \\
\hline Ambidextrous Leadership & 0.293 \\
\hline Innovative Climate & 0.420 \\
\hline F & 57.92 \\
\hline $\mathrm{R}^{2}$ & 0.518 \\
\hline Adjusted $\mathrm{R}^{2}$ & 0.515 \\
\hline
\end{tabular}

\section{Mediation analysis}

Mediation analysis has been performed to check the mediation effect of innovation climate between independent variables (transformational leadership and ambidextrous leadership) and the dependent variable (employee performance). Analysis shows that total effect $(0.472)$ with direct effect $(0.249)$ and indirect effect is $(0.223)$ along with $(p<0.05)$. Between lower confidence level and upper confidence level, there is no zero, so it confirms that innovation climate mediates the relationship between transformational leadership and employee performance. Sobel's test value $(z=4.85)$ also proves the mediation. Similar results also present that innovation climate also mediates the relationship of ambidextrous leadership and employee performance, and Sobel's test also confirms mediation $(z=5.27)$.

\section{DISCUSSION AND CONCLUSION}

The primary purpose of the current study is to find the meaningful relationship of transformational leadership and ambidextrous leadership of an organization's CEO on the overall improvement in the performance of employees. Additionally, the mediating role of innovation climate within the organization is also under consideration. The study's findings revealed that all the hypotheses found positive and significant to which shows the relationship of variables.

First, under sight study shows the relationship between transformational leadership and employee performance in Pakistani textile exporting firms. After analyzing it was found that the impact of transformational leadership on the employee is positive and significant. This is also supported by the results of a previous study conducted by Năstase et al. [32]. These results explain that if the top leadership has the vision to transform their policies according to the latest techniques and include the subordinates in decision-making, it will boost the employees' morale. As a result, they will work with more interest, and the performance of the employees will increase, mainly when the organisation exports its products at the international level. So, the leader should be transformed in their leadership and decisions.

Second, this study aims to find the relationship between ambidextrous leadership and employee performance in the textile exporting sector of Pakistan. Results of the study express that ambidextrous leadership has a significant and positive impact on the performance of employees. Similar findings were also presented by Hamel [25], Drejer [33], Mohsin et al. [34] previously in their study. These results prove that a leader should have ambidextrous abilities to lead its employees because a leader should have more talent and more sense of taking tough decisions compared to its employees. If a leader has less ambidextrous in his judgments and policymaking, it will discourage its employees, which will cause to decline in the performance of the employees. An ambidextrous leader always leads from the front to his employees and gets maximum results using leadership abilities. So, results prove that leaders should

\begin{tabular}{|l|c|c|c|c|c|}
\hline \multicolumn{7}{|c|}{ MEDIATING EFFECT } \\
\hline Transformational. Leadership $\rightarrow$ Innovative Climate $\rightarrow$ EP & Effect & L.C.L & U.C.L & S.E & P \\
\hline Total effect & 0.472 & 0.235 & 0.570 & 0.051 & 0.000 \\
\hline Direct effect & 0.249 & 0.231 & 0.476 & 0.040 & 0.000 \\
\hline Indirect effect & 0.223 & 0.250 & 0.380 & 0.043 & - \\
\hline \multicolumn{1}{|c|}{ Sobel's Test Z=4.85 } & Effect & L.C.L & U.C.L & S.E & P \\
\hline Ambidextrous Leadership $\rightarrow$ Innovative Climate $\rightarrow$ EP & 0.454 & 0.346 & 0.487 & 0.073 & 0.000 \\
\hline Total effect & 0.249 & 0.365 & 0.543 & 0.058 & 0.000 \\
\hline Direct effect & 0.205 & 0.475 & 0.495 & 0.067 & - \\
\hline Indirect effect & & \multicolumn{4}{l|}{} \\
\hline \multicolumn{2}{|c|}{ Sobel's Test Z=5.27 }
\end{tabular}


be more ambidextrous within the organization. This will cause to enhance the performance of employees. Third, this study examines the mediating role of innovation climate between the relationship of transformational leadership and employee performance in the textile exporting firms of Pakistan. Results show that innovation climate partially mediates the relationship between transformational leadership and employee's performance. Similar results were also presented by Gebert et al. [15], Horth and Buchner [24] and Naseem [35] earlier in their studies. Innovation climate is a more critical element when an organization is exporting its products to other countries. If there is a lack of innovation climate with the organization, that organization cannot survive a long in the international market. So, a CEO should have transformational leadership qualities. He should provide an innovative climate in the organization so that employees can work at their total capacity, which will enhance their performance in the organization [36, 37].

Fourth, this study aims to analyze the mediating role of innovation climate between the relationship of ambidextrous leadership and employee performance. Outcomes of this study show that innovation climate partially mediates the relationship between ambidextrous leadership and employee performance. These results are supported by the findings of Giesen et al. [12] and Loewe and Chen [13]. Previously they also presented similar results in their studies. Along with the ambidextrous leadership of the CEO, it is more critical to provide an innovative climate to employees within the organization to enhance their performance of employees. A creative environment in the organization is considered a key element in an exporting firm.

\section{LIMITATIONS AND FUTURE RESEARCH}

The present study contributes many valuable additions to the existing literature. However, besides its contributions, some limitations of the study are significant to discuss here. First, the sample size of the study is minimal, and this might not be presented the whole picture of the textile exporting sector of Pakistan. Secondly, this is an empirical study, and the authors are scholars, so it was impossible to travel for them all over the country. Finally, they delivered questionnaires to respondents through email, which will affect the intention of respondents to fill questionnaires appropriately.

Despite the contributions of this study to the existing literature, there are many aspects yet to discuss for future studies so that the deficiencies in the literature can be covered. For example, future researchers can be enhancing the sample size, and it can be applied to other sectors irrespective of the textile sector. Furthermore, a moderating variable can also be used to measure the relationship between leadership and employee performance.

\section{ACKNOWLEGEMENT}

This paper is partly supported by National Social Science Foundation of China (No. 19ZDA081).

\section{REFERENCES}

[1] Lawton, L.J., Weaver, D.B., Normative and innovative sustainable resource management at birding festivals, In: Tourism Management, 2010, 31, 4, 527-536

[2] Farr, J.L., Sin, H.P., Tesluk, P.E., Knowledge management processes and workgroup innovation, In: Shavinina, L.V. (Ed.), The international handbook on innovation, Oxford, UK: Elsevier Science, 2003, 574-586

[3] Soken, H.N., Kim Barnes, B., What kills innovation? Your role as a leader in supporting an innovative culture, In: Industrial and Commercial Training, 2014, 46, 1, 7-15

[4] Sammut-Bonnici, T., Paroutis, S., Developing a dominant logic of strategic innovation, In: Management Research Review, 2013, 36, 10, 924-938, https://doi.org/10.1108/MRR-08-2013-184

[5] Gul, R.F., Liu, D., Jamil, K., Baig, S.A., Awan, F.H., Liu, M., Linkages between market orientation and brand performance with positioning strategies of significant fashion apparel in Pakistan, In: Fashion and Textiles, 2021, 8, 1, 1-19

[6] Probst, G., Raisch, S., Tushman, M.L., Ambidextrous leadership: Emerging challenges for business and HR leaders, In: Organizational Dynamics, 2011, 40, 4, 326-334

[7] Berends, H., Smits, A., Reymen, I., Podoynitsyna, K., Learning while (re) configuring: Business model innovation processes in established firms, In: Strategic Organization, 2016, 14, 3, 181-219

[8] O'Reilly, C.A., Tushman, M.L., Using culture for strategic advantage: promoting innovation through social control, In: Tushman, M.L., Anderson, P. (Eds.), Managing Strategic Innovation and Change: A Collection of Readings, New York, NY: Oxford University Press, 1997, 200-216

[9] Jamil, K., Hussain, Z., Gul, R.F., Shahzad, M.A., Zubair, A., The effect of consumer self-confidence on information search and share intention, In: Information Discovery and Delivery, 2021, https://doi.org/10.1108/IDD-12-2020-0155

[10] Morris, M.H., Kuratko, D.F., Covin, J.G., Corporate entrepreneurship \& innovation, Cincinnati, OH: Thomson/Southwestern Publishers, 2010

[11] vO'Reilly, C.A., Tushman, M.L., The ambidextrous organization, In: Harvard Business Review, 2004, 82, 4, 74-83

[12] Giesen, E., Riddleberger, E., Christner, R., Bell, R., When and how to innovate your business model, In: Strategy \& Leadership, 2010, 38, 4, 17-26

[13] Loewe, P., Chen, G., Changing your company's approach to innovation, In: Strategy \& Leadership, 2007, 35, 6, $18-26$

[14] Jamil, K., Liu, D., Gul, R.F., Hussain, Z., Mohsin, M., Qin, G., Khan, F.U., Do remittance and renewable energy affect CO2 emissions? An empirical evidence from selected G-20 countries, In: Energy \& Environment, 2021, $0958305 \times 211029636$ 
[15] Gebert, D., Boerner, S., Kearney, E., Fostering team innovation: Why is it important to combine opposing action strategies?, In: Organization Science, 2010, 21, 3, 593-608

[16] O'Reilly, C.A., Caldwell, D.F., Chatman, J.A., Lapiz, M., Self, W., How leadership matters: The effects of leaders' alignment on strategy implementation, In: The Leadership Quarterly, 2010, 21, 1, 104-113

[17] Bass, B.M., Two decades of research and development in transformational leadership, In: European Journal of Work and Organizational Psychology, 1999, 8, 1, 9-32

[18] Jansen, J.J., George, G., Van den Bosch, F.A., Volberda, H.W., Senior team attributes and organizational ambidexterity: The moderating role of transformational leadership, In: Journal of Management Studies, 2008, 45, $5,982-1007$

[19] Naseem, S., Mohsin, M., Hui, W., Liyan, G., Penglai, K., The investor psychology and stock market behavior during the initial era of COVID-19: a study of China, Japan, and the United States, In: Frontiers in Psychology, 2021, 12, 16

[20] Rosing, K., Frese, M., Bausch, A., Explaining the heterogeneity of the leadership-innovation relationship: Ambidextrous leadership, In: The leadership quarterly, 2011, 22, 5, 956-974

[21] Zia-Ur-Rehman, M., Baig, S.A., Abrar, M., Hashim, M., Amjad, F., Baig, I.A., Usman, M., The impact of intellectual capital, organizational capabilities and innovation on firm performance of textile sector: a moderating effect of GSP Plus, In: Industria Textila, 2019, 70, 6, 572-578, http://doi.org/10.35530/IT.070.06.1632

[22] Nemanich, L.A., Vera, D., Transformational leadership and ambidexterity in the context of an acquisition, In: The Leadership Quarterly, 2009, 20, 1, 19-33

[23] Dunnan, L., Jamil, K., Abrar, U., Ali, S., Awan, F. H., Ali, S., Digital Generators and Consumers Buying Behavior, In: 2020 3rd International Conference on Computing, Mathematics and Engineering Technologies (iCoMET), IEEE, 2020, 1-5

[24] Horth, D., Buchner, D., Innovation Leadership: How to use innovation to lead effectively, work collaboratively and drive results, Greensborough, NC: Center for Creative Leadership, 2009

[25] Hamel, G., The why, what, and how of management innovation, In: Harvard Business Review, 2006, 84, 2, 72

[26] West, M.A., Farr, J.L., Innovation at work, In: West, M.A., Farr, J.L. (Eds.), Innovation and creativity at work. Psychological and organizational strategies, Chichester, UK: Wiley, 1990, 3-13

[27] Naseem, S., Fu, G.L., Mohsin, M., Rehman, M.Z.U., Baig, S.A., Semi-Quantitative Environmental Impact Assessment of Khewra Salt Mine of Pakistan: an Application of Mathematical Approach of Environmental Sustainability, In: Mining, Metallurgy \& Exploration, 2020, 37, 1185-1196

[28] Soken, H.N., Kim Barnes, B., What kills innovation? Your role as a leader in supporting an innovative culture, In: Industrial and Commercial Training, 2014, 46, 1, 7-15, https://doi.org/10.1108/ICT-09-2013-0057

[29] Andriopoulos, C., Lewis, M.W., Exploitation-exploration tensions and organizational ambidexterity: Managing paradoxes of innovation, In: Organization Science, 2009, 20, 4, 696-717

[30] Somech, A., The effects of leadership style and team process on performance and innovation in functionally heterogeneous teams, In: Journal of Management, 2006, 32, 1, 132-157

[31] Amjad, F., Baig, S.A., Jamil, K., Amjad, A., Impact of service quality on Loyalty \& Mediating role of Trust: An empirical investigation of Restaurants, In: Journal of Education and Vocational Research, 2017, 8, 4, 6-14

[32] Năstase, M., Burlacu, S., Matis, C., Cristache, N., Roja, A., Coroban, L., Cristescu, I., Perspectives regarding the organizational culture within the Romanian textile industry, In: Industria Textila, 2020, 71, 1, 73-80, http://doi.org/10.35530/IT.071.01.1778

[33] Drejer, A., Strategic innovation: A new perspective on strategic management, In: Handbook of Business Strategy, 2006, 7, 1, 143-147

[34] Mohsin, M., Zhu, Q., Naseem, S., Sarfraz, M., Ivascu, L., Mining Industry Impact on Environmental Sustainability, Economic Growth, Social Interaction, and Public Health: An Application of Semi-Quantitative Mathematical Approach, In: Processes, 2021, 9, 6, 972

[35] Naseem, S., Fu, G.L., Mohsin, M., Aunjam, M.S., Rafiq, M.Z., Jamil, K., Salamat, S., Development of an inexpensive functional textile product by applying accounting cost benefit analysis, Industria Textila, 2020, 71, 1, 17-22, http://doi.org/10.35530/lT.071.01.1692

[36] Sarfraz, M., Mohsin, M., Naseem, S., Kumar, A., Modeling the relationship between carbon emissions and environmental sustainability during COVID-19: A new evidence from asymmetric ARDL cointegration approach, In: Environment, Development and Sustainability, 2021, 1-19

[37] Baig, S.A., Rehman, M.Z.U., Naz, A., Jamil, K., High core self-evaluation maintains patient oriented behavior: A motivational model of reward system, In: Journal of Public Affairs, 2020, e2488

\section{Authors: \\ FAZAL HUSSAIN AWAN ${ }^{1}$, DUNNAN LIU ${ }^{1,2}$, KHALID JAMIL $^{1}$, RANA FAIZAN GUL ${ }^{1}$, ALIYA ANWAR ${ }^{1}$, GUANGYU QIN 1,2}

1School of Economics and Management, North China Electric Power University, Beijing 102206, China e-mail: fazalawan354@gmail.com, liudunnan@163.com, ranafaizangull@yahoo.com, aliyakhalid82@gmail.com, qinguangyu@ncepu.edu.cn

${ }^{2}$ Beijing Key Laboratory of New Energy and Low-Carbon Development, North China Electric Power University, Beijing 102206, China

\section{Corresponding author:}

KHALID JAMIL

e-mail: khalidjamil29@yahoo.com 